\title{
PENGAMBILAN KEPUTUSAN KEUANGAN DENGAN PENDEKATAN ANALISIS RASIO KEUANGAN PADA RSUD CIAWI KABUPATEN BOGOR
}

\section{THE DECISION MAKING OF FINANCE WITH APPROACH OF MONETARY RATIO ANALYSIS AT RSUD CIAWI SUB-PROVINCE OF BOGOR}

\author{
F. Susandra, I. Gandara \\ Program Studi Akuntansi Fakultas Ekonomi Universitas Djuanda Bogor \\ Jl. Tol Ciawi No. 1, Kotak Pos 35, Kode Pos 16720, Telp/Fax: (0251)-8245155 \\ Email : Farizka.susandra@unida.acid, itang gandara@yahoo.com
}

\begin{abstract}
Research comparative descriptive is a study to analyze the financial ratios as a financial decision on hospitals Ciawi Bogor Regency using ratio analysis, liquidity, solvency, activity, profitability, and 7 indicators of financial ratios and other aspects of compliance management BLUD in assessing the financial performance of hospitals ie cash ratio, current ratio, accounts receivable collection period, fixed asset turnover, return for an investment / on assets, return for equity and operating income over operating costs. The results showed that the analysis of the financial performance of Bogor Regency Hospital Ciawi based analysis of the liquidity ratio, solvency, activity and profitability showed good performance and is based on financial performance indicators of hospitals, the financial performance of the Bogor Regency Ciawi Hospital in 2011-2014 included in honors / healthy. Financial decision that should be done is to maintain the level of liquidity, solvency, activity. For the assessment of the level of profitability is still low can be done through the improvement of service in order to revenues from services is increasing as the improvement of facilities and infrastructure of hospitals, increased utilization of asset value, and the increase in the number of employees in the service and cost control services and general administrative expenses are still high and if possible there are adjustments to tariffs.
\end{abstract}

Keywords: Liquidity, Solvency, activity, profitability, and financial decision making.

\begin{abstract}
ABSTRAK
Penelitian deskriptif komparatif ini merupakan penelitian untuk menganalisis rasio keuangan sebagai bahan pengambilan keputusan keuangan pada RSUD Ciawi Kabupaten Bogor dengan menggunakan analisis rasio likuiditas, solvabilitas,aktivitas,profitabilitas, dan 7 indikator rasio-rasio keuangan dan aspek kepatuhan pengelolaan BLUD dalam penilaian kinerja keuangan rumah sakit yaitu rasio kas, rasio lancar, periode penagihan piutang, perputaran asset tetap, imbalan investasi/atas asset, imbalan atas equitas dan pendapatan operasional atas biaya operasional. Hasil penelitian menunjukkanbahwa analisis kinerja keuangan RSUD Ciawi Kabupaten Bogor berdasarkan analisis rasio likuiditas, solvabilitas, aktivitas, dan profitabilitasmenunjukkan kinerja yang baik dan berdasarkan indikator kinerja keuangan rumah sakit,kinerja keuangan RSUD Ciawi Kabupaten Bogor dari tahun 2011-2014 termasuk dalam predikat tinggi/sehat.Pengambilan keputusan keuangan yang sebaiknya dilakukan yaitu mempertahankan tingkat likuiditas, solvabilitas, aktivitas. Untukpenilaian tingkat profitabilitas yang masih rendah dapat dilakukan melalui peningkatan pelayanan agar pendapatan usaha dari jasa layanan semakin meningkat seperti peningkatan sarana dan prasarana rumah sakit, peningkatan pemanfaatan nilai asset, dan penambahan jumlah pegawai pada bagian pelayanan dan pengendalian biaya layanan dan biaya administrasi umum yang masih tinggiserta jika memungkinkan ada penyesuaian terhadap tarif pelayanan.
\end{abstract}

Kata Kunci : Likuiditas, Solvabilitas, Aktivitas, Profitabilitas,dan Pengambilan keputusan keuangan. 


\section{PENDAHULUAN}

Berdasarkan Undang-Undang Nomor 17 tahun 2003 tentang Keuangan Negara, Undang- undang No.1 Tahun 2004 tentang Perbendaharaan Negara, dan UU No.15 Tahun 2005 tentang Pemeriksaan Keuangan Negara, instansi pemerintah yang tugas pokok dan fungsinya memberikan pelayanan kepada masyarakat dapat menerapkan pola pengelolaan keuangan yang fleksibel, berupa keleluasaan untuk menerapkan praktekpraktek bisnis yang sehat dalam rangka memaksimalkan pelayanan kepada masyarakat dengan tetap menonjolkan produktivitas, efisiensi, dan efektifitas melalui Badan Layanan Umum. BLU pada dasarnya adalah alat untuk meningkatkan kinerja pelayanan publik melalui penerapan manajemen keuangan yang berbasis pada hasil, profesionalitas, akuntabilitas dan transparansi. Untuk dapat menjadi BLU, suatu instansi harus memenuhi tiga persyaratan pokok, yaitu persyaratan substantif, yang terkait dengan penyelanggaraan layanan umum, persyaratan teknis yang terkait dengan kinerja pelayanan dan kinerja keuangan, serta persyaratan administratif terkait dengan terpenuhinya dokumen seperti pola tata kelola, rencana strategis bisnis, standar layanan minimal, laporan keuangan pokok, dan laporan audit/bersedia untuk diaudit.

Rumah sakit sebagai salah satu institusi pelayanan publik memegang peranan penting bagi peningkatan derajat kesehatan masyarakat. Rumah sakit dituntut untuk dapat melayani masyarakat, dapat berkembang dan mandiri serta harus mampu bersaing dan memberikan pelayanan yang bermutu dan terjangkau bagi masyarakat. Dengan semakin tingginya tuntutan bagi rumah sakit untuk meningkatkan pelayanannya, banyak permasalahan yang muncul terkait dengan terbatasnya anggaran yang tersedia bagi operasional rumah sakit, alur birokrasi yang terlalu panjang dalam proses pencairan dana, aturan pengelolaan keuangan yang menghambat kelancaran pelayanan dan sulitnya untuk mengukur kinerja, sementara rumah sakit memerlukan dukungan SDM, teknologi, dan modal yang sangat besar. Seiiring dengan terbitnya Peraturan Pemerintah Nomor 23 Tahun 2005 sebagai peraturan pelaksanaan dari Undang undang tersebut diatas tentang Pola Pengelolaan
Keuangan Badan Layanan Umum (PPK-BLU) ini rumah sakit diharapkan dapat meningkatkan profesionalisme, mendorong enterpreneureship, transparansi, dan akuntabilitas dalam rangka pelayanan publik, sesuai dengan tiga pilar yang diharapkan dari pelaksanaan PPK-BLU ini, yaitu mempromosikan peningkatan kinerja pelayanan publik, fleksibilitas pengelolaan keuangan dan tata kelola yang baik.

Perubahan Pola Pengelolaan Keuangan menjadi Badan Layanan Umum (PPK-BLU), Rumah Sakit Pemerintah menjadi suatu badan usaha (Business Entity) seperti umumnya dilakukan oleh dunia bisnis/swasta yang setiap akhir tahun perlu menyusun laporan keuangan dengan mengacu kepada Standar Akuntansi Keuangan (SAK) yang digunakan untuk menyediakan informasi yang relevan mengenai posisi keuangan dan seluruh transaksi yang dilakukan dalam satu periode pelaporan entitas terhadap berbagai pihak seperti bankir, pemegang saham, investor/kreditur, instansi pemerintah dan karyawan perusahaan itu sendiri. Peraturan Menteri Dalam Negeri RI Nomor 61 Tahun 2007 Tanggal 7 November 2007 tentang Pedoman teknis pengelolaan keuangan Badan Layanan Umum Daerah bahwa pendapatan BLUD dapat bersumber dari jasa layanan, hibah, hasil kerja sama dengan pihak lain, APBD, APBN dan lain-lain pendapatan BLUD yang sah. Kemudian berdasarkan Peraturan Direktur Jenderal Perbendaharaan Direktorat Jenderal Perbendaharaan Kementerian Keuangan Republik Indonesia Nomor Per36/PB/2012 Tanggal 25 Oktober 2012 memasukan 7 indikator yang diukur dalam penilaian kinerja atau kesehatan keuangan rumah sakit, yaitu rasio posisi kas (cash ratio),rasio lancar (current ratio), rasio periode penagihan piutang (collection period), rasio perputaran asset tetap (fixed asset turnover), rasio imbalan atas asset tetap (return on asset), rasio imbalan equitas (return on equity), dan rasio pendapatan PNPB terhadap biaya operasional.

Dengan analisa rasio keuangan, maka dapat diketahui kinerja keuangan sebuah rumah sakit atau perusahaan pada umumnya, dimana analisa rasio keuangan adalah indeks yang menghubungkan dua angka akuntansi dan diperoleh dengan membagi satu angka dengan angka lainnya. Analisa Rasio Keuangan 
melibatkan dua jenis perbandingan yaitu sebagai berikut.

1. Analis dapat membandingkan rasio saat ini dengan rasio masa lalu dan akan datang dalam perusahaan yang sama. Jika Rasio Keuangan diurutkan dalam beberapa periode tahun, analis dapat menentukan apakah terdapat perbaikan atau penurunan dalam kondisi keuangan dan kinerja (Performance) perusahaan.

2. Melibatkan perbandingan rasio satu perusahaan dengan perusahaan perusahaan sejenis atau dengan rata rata industri pada titik waktu yang sama.
Perbandingan ini memberikan pandangan mendalam tentang kondisi keuangan dan kinerja (Performance) relative dari perusahaan ( Sutojo;1997:133).

Rumah Sakit Umum Daerah Ciawi Kabupaten Bogor merupakan sebuah rumah sakit milik Pemerintah Daerah Kabupaten Bogor yang menerapkan Pola Pengelolaan Keuangan Badan Layanan Umum (PPK-BLU), maka pengelolaannya seperti dunia bisnis pada umumnya yaitu perlu menyusun Laporan Keuangan, dimana analisa rasio atas Laporan Keuangan dapat dipergunakan untuk berbagai pengambilan keputusan.

Tabel 1. Surplus Operasional RSUD Ciawi Kabupaten Bogor Tahun 2011-2014

\begin{tabular}{|c|c|c|c|}
\hline Tahun & Surplus Operasional & \multicolumn{2}{c|}{ Perubahan (\%) } \\
\hline & $(\mathrm{Rp})$ & Naik & Turun \\
\hline 2011 & 2.380 .277 .937 & $1.958,81 \%$ & n.a \\
\hline 2012 & 49.005 .438 .163 & & $1.962 \%$ \\
\hline 2013 & 2.376 .559 .880 & - & - \\
\hline 2014 & 25.223 .576 .395 & - & $961,35 \%$ \\
\hline
\end{tabular}

Sumber : Data laporan keuangan RSUD Ciawi Kab. Bogor

Berdasarkan tabel 1.1 diatas surplus operasional RSUD Ciawi Kabupaten Bogor tahun 2011 sampai dengan 2014, bahwa pertumbuhan surplus operasional nampak berfluktuasi, pada tahun 2013 surplus operasional mengalami penurunan yang signifikan, penurunan ini berdasarkan data laporan keuangan disebabkan adanya penurunan pendapatan bersih BLUD yang bersumber dari APBD sebesar 57,38 \% dari tahun 2012 dan adanya kenaikan pada biaya operasional sebesar 33,19\% dari tahun 2012. Kenaikan dan penurunan surplus operasional diatas akan sangat berpengaruh terhadap tingkat profitabilitas organisasi dan pengambilan keputusan keuangan.

\section{METODE PENELITIAN}

Desain penelitian menggambarkan, meneliti, mengungkapkan dan menjelaskan bagaimana tahapan-tahapan dalam menganalisa Rasio-rasio keuangan atas laporan keuangan serta prosedur apa saja yang harus dilakukan kemudian menarik kesimpulan dari obyek yang diteliti. Dalam penelitian ini, sumber data yang digunakan adalah data sekunder yaitu data yang didapat dari catatan, buku, dan laporan keuangan publikasi perusahaan (V.Wiratna Sujarweni: 2014:74).Data tersebut berupa Laporan

c. Rasio Profitabilitas : rasio yang digunakan untuk menilai kemampuan
Keuangan Rumah Sakit Umum Daerah Ciawi Kabupaten Bogor tahun 2011 sampai dengan tahun 2014. Pengumpulan data yang dilakukan dengan menggunakan sumber data sekunder dan dari berbagai sumber dengan cara penelitian kepustakaan (Library Riset,)dan penelitian lapangan (Field Riset) melalui wawancara dan observasi terhadap obyek yang diteliti.

Adapun analisa data yang digunakan adalah analisa ratio dan deskriptif komparatif. Metode analisis berdasarkan laporan keuangan yang terdiri dari neraca dan laporan laba/rugi. Tehnik dalam menganalisis laporan keuangan ini adalah sebagai berikut:

1. Rasio-rasio Keuangan, yang terdiri dari :

a. Rasio Likuiditas : Rasio likuiditas digunakan untuk mengukur kemampuan perusahaan dalam memenuhi kewajiban-kewajiban jangka pendek yang segera harus dipenuhi.

b. Rasio Solvabilitas : rasio yang menunjukkan kapasitas dan kemampuan perusahaan untuk memenuhi kewajiban-kewajiban jangka panjangnya. Besarnya ukuran umum yang dipakai adalah $200 \%$ atau 2:1 yang berarti dua kali dari total hutang perusahaan dikatakan solvable.

perusahaan untuk memperoleh keuntungan. 
2. Metode deskriptif komparatif, yaitu membandingkan laporan keuangan beberapa tahun sebelumnya dari Rumah Sakit Umum Daerah Ciawi Kabupaten Bogor yang menjadi objek penelitian. Penulis melakukan analisis terhadap laporan keuangan dalam empat tahun yaitu dari tahun 2011 - 2014.

\section{HASIL DAN PEMBAHASAN}

\section{Analisa Penilaian Likuiditas}

Penilaian likuiditas adalah penilaian untuk mengukur kemampuan perusahaan dalam memenuhi kewajiban jangka pendeknya. Perhitungan rasio-rasio likuiditas dapat dilihat dibawah ini.

\section{Grafik Perkembangan Rasio-rasio Likuiditas RSUD CIAWI KABUPATEN BOGOR \\ Tahun 2011-2014}

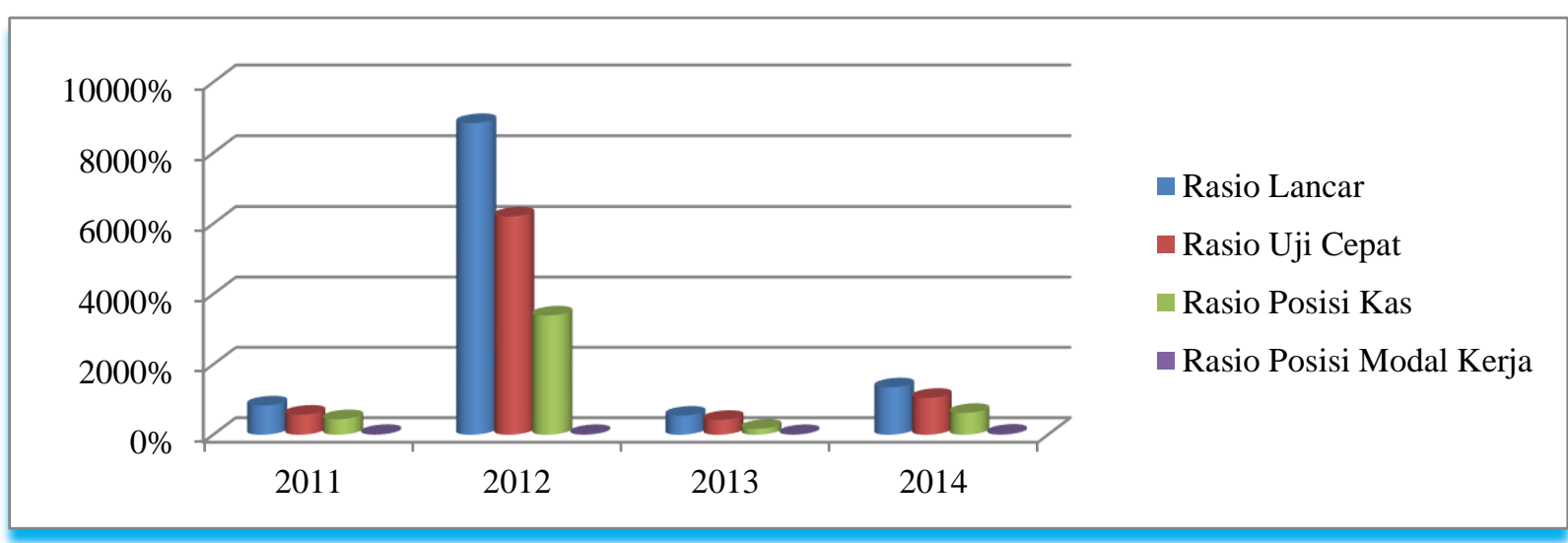

Sumber : Data Lap. Keuangan RSUD Ciawi Tahun 2011-2014 yang diolah penulis.

Berdasarkan tabel 4.1. dan grafik perkembangan rasio-rasio likuiditas diatas, maka dapat diuraikan penilaian sebagai berikut.

a. Rasio lancar (Current asset)

Rasio lancar RSUD Ciawi Kabupaten Bogor selama periode analisis menunjukkan nilai yang berfluktuatif. Pada pos perkiraan buku besar hutang lancar, pos hutang usaha mempengaruhi nilai total hutang lancar selama tahun 2011 sampai dengan 2014. Hal utama yang menyebabkan penurunan dan kenaikan nilai rasio lancar ini adanya kenaikan dan penurunan pada hutang usaha, ini merupakan kewajiban RSUD Ciawi terhadap pihak ketiga. Nilai Rasio Lancar apabila dirata-ratakan mencapai 2890 persen artinya Rp100,hutang lancar dijamin oleh Rp2890 asset lancar.

b. Rasio uji cepat (Quick ratio)

Rasio Uji Cepat RSUD Ciawi Kabupaten Bogor secara umum menunjukan nilai yang berfluktuatif selama periode analisis, rasio ini mengikuti pola yang hampir sama dengan nilai rasio lancarnya, seperti halnya rasio lancar, nilai rasio uji cepatpun mengalami penurunan. Nilai rasio uji cepat apabila dirata-ratakan mencapai 2060 persen artinta Rp100,- hutang lancar dijamin oleh Rp2060,- asset lancar RSUD Ciawi yang likuid karena tidak memperhitungkan nilai persediaan. Hal ini tentunya akan membuat kreditur jangka pendek tidak perlu hawatir akan keadaan kondisi keuangan rumah sakit yang tidak dapat membayar hutang jangka pendeknya sesuai dengan waktu yang ditetapkan.

c. Rasio posisi kas (Cash ratio)

Rasio posisi kas (cash ratio) RSUD Ciawi Kabupaten Bogor selama tahun 20112014, menunjukkan nilai yang berfluktuatif. Apabila dirata-ratakan nilai rasio posisi kas selama periode analisis bernilai 1155 persen. Hal ini berarti setiap Rp100,- hutang lancar rumah sakit dapat dijamin oleh Rp1155,- kas rumah sakit yang merupakan asset yang paling likuid.

d. Rasio posisi modal kerja (working capital to total asset)

Penilaian rasio posisi modal kerja terhadap total asset (working capital to total asset), menunjukkan nilai yang berfluktuatif. .Apabila dirata-ratakan bernilai 22 persen artinya dari setiap Rp100,- asset rumah sakit hanya $\mathrm{Rp} 22$,- yang dipergunakan untuk modal kerja. Hal ini menunjukkan nilai yang sangat baik sehingga tidak ada 
kekhawatiran bagi para kreditur jangka pendek terhadap kondisi keuangan RSUD

\section{Analisa Penilaian Solvabilitas}

Penilaian solvabilitas adalah penilaian untuk mengukur kemampuan perusahaan
Ciawi Kabupaten Bogor.

dalam memenuhi kewajiban jangka panjang. Perhitungan rasio-rasio solvabilitas dapat dilihat dibawah ini.

Grafik Perkembangan Rasio-rasio Solvabilitas

\section{RSUD CIAWI KABUPATEN BOGOR Tahun 2011-2014}

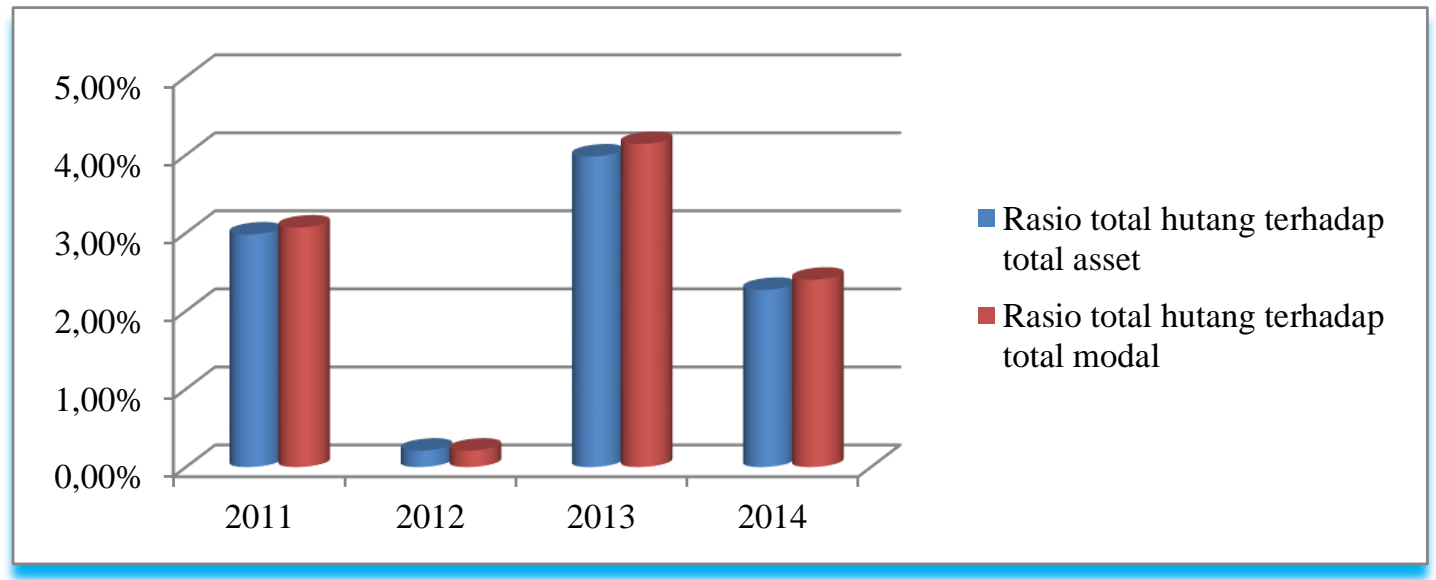

Sumber : Data Lap. Keuangan RSUD Ciawi Tahun 2011-2014 yang diolah penulis.

Berdasarkan grafik perkembangan rasio solvabilitas diatas, maka dapat diuraikan penilaian sebagai berikut.

a. Rasio total hutang terhadap total asset

Rasio total hutang terhadap total asset selama periode analisis (2011-2014) menunjukan nilai yang berfluktuatif. Nilai rata-rata rasio total hutang terhadap total asset sebesar 2,36 persen berarti hanya sebesar Rp2,36 dari Rp100,- asset dijadikan jaminan pelunasan hutang. Semakin kecil tingkat rasio hutang terhadap total asset, maka akan semakin

\section{Analisis Penilaian Aktivitas}

Penilaian aktivitas adalah penilaian untuk mengukur aktivitas yang dilakukan perusahaan dalam menjalankan operasinya,

kecil tingkat resiko keuangan jangka panjang yang dihadapi rumah sakit.

b. Rasio total hutang terhadap total modal Rasio total hutang terhadap total modal menunjukkan nilai yang berfluktuatif. Nilai rata-rata rasio total hutang terhadap total modal sebesar 2,45 persen, artinya hanya sebesar 2,45 persen modal rumah sakit dibelanjai oleh pihak luar. Hal ini menunjukkan nilai yang sangat baik dan tidak ada kekhawatiran kondisi keuangan rumah sakit dalam menutup hutanghutangnya.

baik dalam menjalankan penjualan, pembelian, pengelolaan persediaan, penagihan piutang dan kegiatan lainnya.

Grafik Perkembangan Rasio-rasio Aktivitas RSUD CIAWI KABUPATEN BOGOR Tahun 2011-2014

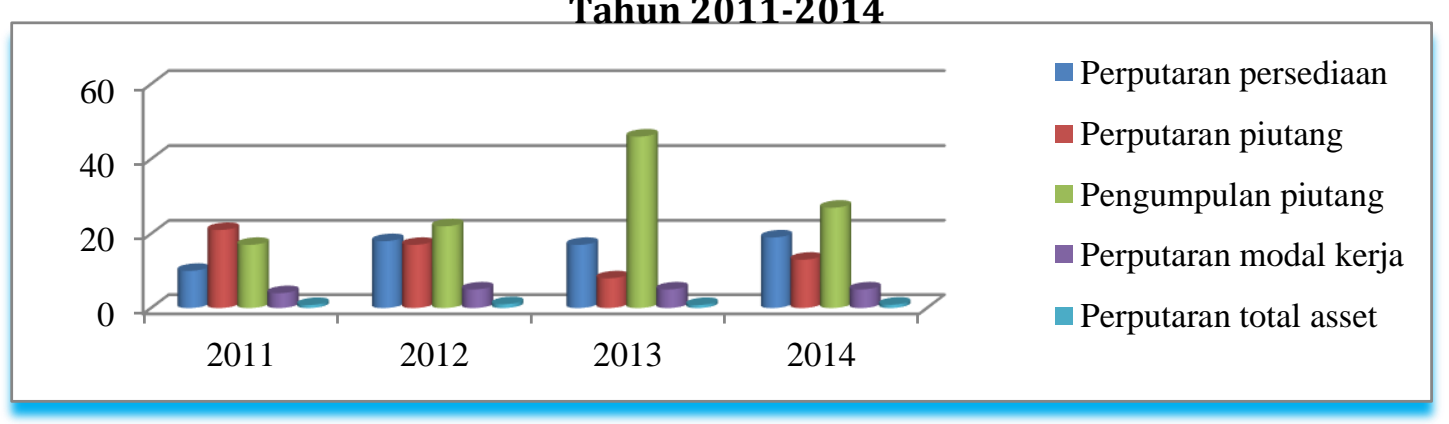

Sumber : Data Lap. Keuangan RSUD Ciawi Tahun 2011-2014 yang diolah penulis. 
Berdasarkan grafik diatas, maka dapat diuraikan penilaian sebagai berikut.

a. Rasio perputaran persediaan

Rasio perputaran persediaan (inventori turnover) menggambarkan berapa kali dana yang tertanam dalam persediaan berputar selama satu tahun. Perkembangan dari tingkat perputaran persediaan selama periode analisis menunjukkan nilai yang berfluktuatif. Nilai rasio perputaran persediaan yang rata-rata berputar mencapai 16 kali selama periode analisis, hal ini merupakan indikator bahwa RSUD Ciawi Kabupaten Bogor merupakan suatu kesatuan usaha (Business entity) yang sudah meraih pangsa pasar yang cukup besar.

b. Rasio perputaran piutang

Rasio perputaran piutang (receivable turnover) menggambarkan posisi piutang dan taksiran pengembaliannya atau menggambarkan seberapa besar penjualan perusahaan yang dilakukan dengan sistem kredit. Perkembangan dari tingkat perputaran piutang RSUD Ciawi Kabupaten Bogor selama periode analisis menunjukkan nilai yang cenderung menurun. Nilai rasio perputaran piutang rata-rata mencapai 15 kali artinya dana yang tertanam dalam piutang berputar dalam satu tahun sebanyak 15 kali. Hal ini menunjukkan nilai yang cukup baik, dimana piutang dapat dengan cepat direalisir menjadi kas dalam waktu kurang dari 1 bulan.

c. Rasio tingkat pengumpulan piutang menggambarkan waktu pengumpulan piutang dan akhirnya dapat diketahui berapa hari piutang tidak dapat ditagih atau days of receivable yang umumnya 1 sampai dengan 2 bulan. Apabila di rataratakan selama 28 hari. Perputaran dana yang tertanam dalam piutang dan pengumpulan piutang yang relatif cepat, hal ini menunjukkan keeffektifan kegiatan operasional rumah sakit.

d. Rasio perputaran modal kerja menggambarkan keeffektifan perputaran modal kerja dan menunjukkan hubungan antara modal kerja dengan penjualan serta menunjukkan banyaknya penjualan yang dapat diperoleh rumah sakit (jumlah rupiah) untuk tiap rupiah modal kerja. Selama periode analisis perputaran modal kerja menunjukkan nilai yang cenderung stabil. Apabila dirata-ratakan nilai rasio ini hampir mencapai 5 kali, artinya bahwa Rp1,- modal kerja dapat menghasilkan Rp5,- penjualan.

e. Rasio tingkat perputaran asset tetap Rasio tingkat perputaran asset tetap (Fixed Asset Turnover) menggambarkan kemampuan dana yang tertanam dalam asset tetap berputar dalam suatu periode tertentu atau kemampuan modal yang diinvestasikan untuk menghasilkan revenue/penjualan. Semakin tinggi nilai rasio ini maka semakin baik pula produktivitas asset tetap menghasilkan penjualan yang akhirnya diharapkan akan menghasilkan laba yang besar. Nilai yang rendah dari rasio ini dapat dijadikan indikator dari kurang produktifnya asset tetap perusahaan atau adanya kelebihan investasi (over investment) pada asset perusahaan. Nilai rasio perputaran asset tetap rumah sakit selama periode analisis menunjukkan nilai yang berfluktuatif. Apabila melihat patokan umum rasio ini dinilai rendah, mungkin karena rumah sakit dalam kegiatannya melayani kesehatan masyarakat yang tidak berorientasi kepada profit atau harus ada evaluasi terhadap pemanfaatan nilai asset tetap sehingga tidak terjadi adanya asset tetap yang kurang produktif.

f. Rasio tingkat perputaran total asset

Rasio tingkat perputaran total asset (total asset turnover) menggambarkan kemampuan dana yang tertanam dalam keseluruhan asset berputar dalam suatu periode tertentu atau kemampuan modal yang diinvestasikan untuk menghasilkan revenue/penjualan. Semakin tinggi nilai rasio ini maka semakin baik pula produktivitas total asset dalam menghasilkan penjualan yang akhirnya diharapkan akan menghasilkan laba yang besar. Nilai yang rendah dari rasio ini dapat dijadikan indikator dari kurang produktifnya asset perusahaan atau adanya kelebihan investasi (over investment) pada asset perusahaan. Nilai rasio perputaran total asset rumah sakit selama periode analisis menunjukkan nilai yang berfluktuatif. Apabila dirata-ratakan nilai rasio sebesar 0.99 kali artinya setiap Rp100,- asset rumah sakit dapat menghasilkan penjualan Rp99. Apabila melihat patokan umum rasio ini dinilai 
rendah, mungkin karena rumah sakit dalam kegiatannya melayani kesehatan masyarakat yang tidak berorientasi kepada profit atau harus ada evaluasi terhadap

\section{Analisis Penilaian Profitabilitas}

Penilaian profitabilitas menggamba-rkan kemampuan perusahaan dalam menghasilkan pemanfaatan nilai asset sehingga tidak terjadi adanya asset yang kurang produktif.

keuntungan melalui semua kemampuan dan sumber daya yang ada. Perhitungan rasio-rasio aktivitas dapat dilihat dibawah ini.

\section{Grafik Perkembangan Rasio-rasio Profitabilitas RSUD CIAWI KABUPATEN BOGOR Tahun 2011-2014}

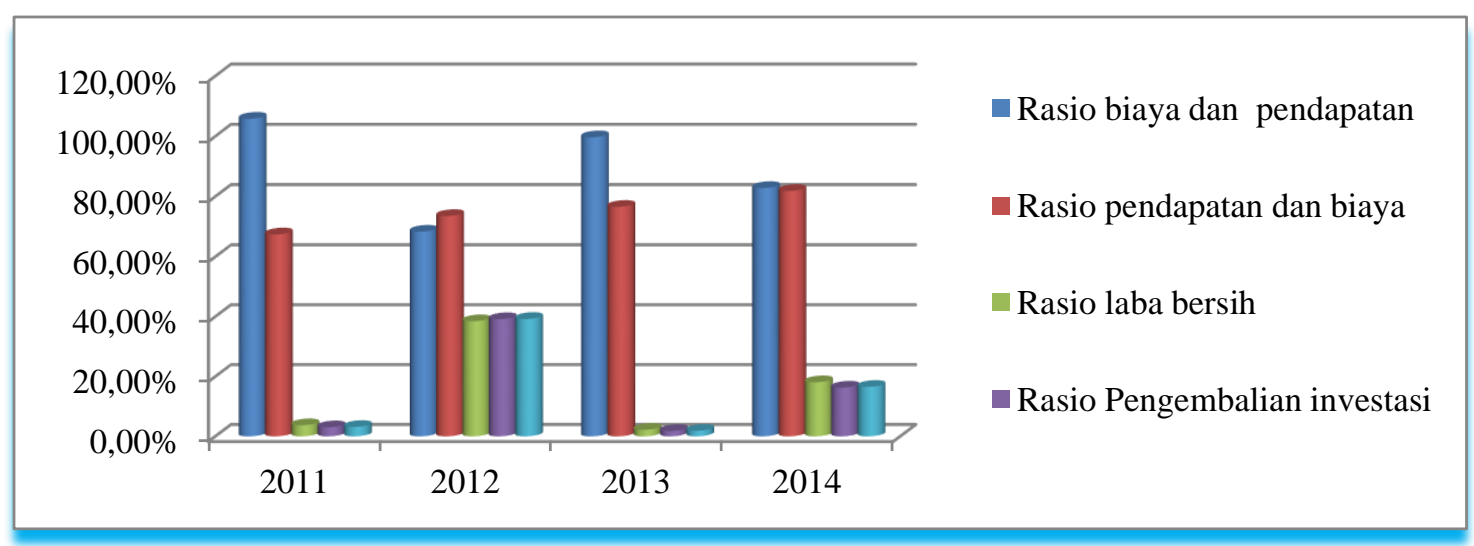

Sumber : Data Lap. Keuangan RSUD Ciawi Tahun 2011-2014 yang diolah penulis.

Berdasarkan tabel 4.4 dan grafik diatas, maka dapat diuraikan penilaian sebagai berikut.

a. Hasil penilaian rasio-rasio profitabilitas RSUD Ciawi Kabupaten Bogor selama periode analisis tahun 2011-2014 menunjukkan nilai yang berfluktuatif. Pada tahun 2012 semua nilai rasio mengalami kenaikan dari tahun 2011, kecuali nilai rasio operasi (Base Cost Pro- ductivity/ operating ratio ) dan nilai rasio pendapatan terhadap biaya yang mengalami penurunan. Kenaikan nilai rasio-rasio profitabilitas ini disebabkan adanya pendapatan rumah sakit dari APBD sebesar Rp 80.999.959.906,-

b. Pada tahun 2013 semua nilai rasio profitabilitas mengalami penurunan dengan penurunan rata-rata mencapai 95 persen dari tahun 2012. Penurunan tersebut seiring dengan turunnya pendapatan rumah sakit yang bersumber dari APBD dan tingginya biaya operasi dan biaya umum dan administrasi, hal ini dapat dilihat dari perhitungan rasio operasi/POBO (Base Cost Pro- ductivity/ operating ratio ) yang mencapai 99,65 persen, artinya setiap Rp100,pendapatan/penjualan memerlukan biaya sebesar Rp99,65,-. Kemudian pada tahun 2014 semua rasio profitabilitas mengalami kenaikan, hal ini disebabkan meningkatnya jumlah pendapatan rumah sakit, kenaikan pendapatan sebesar $29,70 \%$ dari tahun 2013, yang mengakibatkan dana yang tersedia untuk laba bersih/surplus operasional menjadi naik sehingga sangat berpengaruh terhadap kenaikan pengembalian investasi dan pengembalian modal.

Penilaian Kinerja Keuangan Satuan Kerja Badan Layanan Umum Bidang Layanan Kesehatan RSUD Ciawi Kabupaten Bogor

Penilaian kinerja keuangan Satuan Kerja Badan Layanan Umum Daerah RSUD Ciawi Kabupaten Bogor berdasarkan Peraturan Direktur Jenderal Perbendaharaan Direktorat Jenderal Perbendaharaan Kementerian Keuangan Republik Indonesia Nomor Per36/PB/2012 Tanggal 25 Oktober 2012 adalah penjumlahan total skor dari nilai Aspek keuangan yang terdiri dari Rasio posisi kas (cash ratio), Rasio lancar (current ratio), Rasio periode penagihan piutang (collection period), Rasio perputaran asset tetap (fixed asset turnover), Rasio imbalan atas asset tetap (return on asset), Rasio imbalan equitas (return 
on equity), dan Rasio pendapatan PNPB terhadap biaya operasional dengan nilai aspek Kepatuhan pengelolaan keuangan BLUD yang terdiri dari Rencana Bisnis Anggaran, Penyampaian laporan keuangan berdasarkan Standar Akuntansi Keuangan, Surat perintah pengesahan pendapatan dan belanja BLU, Tarif layanan, Sistem akuntansi, Persetujuan

Tabel 2. Rekapitulasi Indikator Rasio-rasio Keuangan dan Aspek Kepatuhan Pengelolaan BLUD dalam Penilaian Kinerja Keuangan RSUD CIAWI Kabupaten Bogor Tahun 2011-2014

\begin{tabular}{|c|c|c|c|c|c|c|c|c|c|}
\hline \multirow{2}{*}{ No } & \multirow{2}{*}{$\begin{array}{l}\text { Aspek Keuangan } \\
\text { /Rasio Keuangan }\end{array}$} & \multicolumn{4}{|c|}{ Besar nilai \% } & \multicolumn{4}{|c|}{ Skor } \\
\hline & & 2011 & 2012 & 2013 & 2014 & 2011 & 2012 & 2013 & 2014 \\
\hline 1 & Rasio Posisi Kas : & $441 \%$ & $3392 \%$ & $166 \%$ & $619 \%$ & 6 & 2 & 4 & 2 \\
\hline $\mathrm{a}$ & Rasio Lancar & $831 \%$ & $8841 \%$ & $541 \%$ & $1346 \%$ & 13 & 13 & 10,4 & 13 \\
\hline $\mathrm{b}$ & $\begin{array}{l}\text { Rasio Periode } \\
\text { Penagihan Piutang }\end{array}$ & 17 hari & 22 hari & 46 hari & 27 hari & 10 & 8 & 6 & 8 \\
\hline c & $\begin{array}{l}\text { Rasio Perputaran Asset } \\
\text { Tetap }\end{array}$ & $110 \%$ & $126 \%$ & $104 \%$ & $114 \%$ & 10 & 10 & 10 & 10 \\
\hline$d$ & $\begin{array}{l}\text { Rasio Imbalan atas } \\
\text { Asset }\end{array}$ & $3,04 \%$ & $39,15 \%$ & $1,79 \%$ & $16,28 \%$ & 2 & 5 & 1 & 5 \\
\hline $\mathrm{e}$ & Rasio Imbalan Equitas & $3,14 \%$ & $39,23 \%$ & $1,87 \%$ & $16,54 \%$ & 2 & 5 & 1 & 5 \\
\hline \multirow[t]{2}{*}{$\mathrm{f}$} & $\begin{array}{l}\text { Rasio pendapatan PNBP } \\
\text { terhadap biaya operasi }\end{array}$ & $67,42 \%$ & $73,53 \%$ & $76,57 \%$ & $81,86 \%$ & 9,6 & 10,8 & 12 & 12 \\
\hline & $\begin{array}{l}\text { Jumlah Skor Aspek } \\
\text { Keuangan / Rasio } \\
\text { Keuangan }\end{array}$ & & & & & 52,6 & 53,8 & 44,4 & 55 \\
\hline 2 & $\begin{array}{l}\text { Aspek Kepatuhan } \\
\text { Pengelolaan Keuangan } \\
\text { BLUD : }\end{array}$ & & & & & & & & \\
\hline a & $\begin{array}{l}\text { Rencana Bisnis } \\
\text { Anggaran }\end{array}$ & Ya & Ya & Ya & Ya & 5 & 5 & 5 & 5 \\
\hline $\mathrm{b}$ & $\begin{array}{l}\text { Penyampaian laporan } \\
\text { keuangan berdasarkan } \\
\text { standar Akuntansi } \\
\text { Keuangan }\end{array}$ & Ya & Ya & Ya & $\mathrm{Ya}$ & 11 & 11 & 11 & 11 \\
\hline $\mathrm{c}$ & $\begin{array}{l}\text { Surat perintah penge } \\
\text { sahan pendapatan dan } \\
\text { belanja BLU }\end{array}$ & Ya & $\mathrm{Ya}$ & Ya & $\mathrm{Ya}$ & 7 & 7 & 7 & 7 \\
\hline $\mathrm{d}$ & Tarif layanan & $\mathrm{Ya}$ & Ya & Ya & Ya & 3 & 3 & 3 & 3 \\
\hline $\mathrm{e}$ & Sistem Akuntansi & Ya & Ya & $\mathrm{Ya}$ & $\mathrm{Ya}$ & 3 & 3 & 3 & 3 \\
\hline $\mathrm{f}$ & Persetujuan rekening & $\mathrm{Ya}$ & $\mathrm{Ya}$ & $\mathrm{Ya}$ & $\mathrm{Ya}$ & 1 & 1 & 1 & 1 \\
\hline g & $\begin{array}{l}\text { Standar operating } \\
\text { procedures (SOP) } \\
\text { pengelolaan kas }\end{array}$ & Ada & Ada & Ada & Ada & 1 & 1 & 1 & 1 \\
\hline $\mathrm{h}$ & $\begin{array}{l}\text { SOP pengelolaan } \\
\text { piutang }\end{array}$ & Ada & Ada & Ada & Ada & 1 & 1 & 1 & 1 \\
\hline $\mathrm{i}$ & SOP pengelolaan utang & Ada & Ada & Ada & Ada & 1 & 1 & 1 & 1 \\
\hline j & $\begin{array}{l}\text { SOP pengadaan barang } \\
\text { dan jasa }\end{array}$ & Ada & Ada & Ada & Ada & 1 & 1 & 1 & 1 \\
\hline \multirow[t]{3}{*}{$\mathrm{k}$} & $\begin{array}{l}\text { SOP pengelolaan } \\
\text { barang inventaris }\end{array}$ & Ada & Ada & Ada & Ada & 1 & 1 & 1 & 1 \\
\hline & \multicolumn{5}{|c|}{ Jumlah Skor Aspek Kepatuhan Pengelolaan Keuangan } & 35 & 35 & 35 & 35 \\
\hline & Total Skor & & & & & 87,6 & 88,8 & 79,4 & 90 \\
\hline
\end{tabular}

Sumber : Data Lap. Keuangan RSUD Ciawi Tahun 2011-2014 yang diolah penulis. rekening, Standar operating procedures (SOP) pengelolaan kas, SOP pengelolaan piutang, SOP pengelolaan utang, SOP pengadaan barang dan jasa, SOP pengelolaan barang inventaris.

Untuk menghitung skor dari masingmasing-masing aspek diatas dapat dilihat pada tabel berikut.ini : 
Hasil penilaian kinerja keuangan Satuan Kerja Badan Layanan Umum Daerah RSUD Ciawi Kabupaten Bogor pada tahun 2011-2012 masuk ke dalam range $80<\mathrm{TS} \leq 90$. Dengan demikian kinerja keuangan RSUD Ciawi masuk ke dalam predikat TINGGI AA. Sedangkan hasil kinerja keuangan pada tahun 2013 masuk ke dalam range $70<\mathrm{TS} \leq 80$, maka kinerja keuangan RSUD Ciaw masuk ke dalam predikat TINGGI A. Kemudian pada tahun 2014 masuk ke dalam range $80<\mathrm{TS} \leq 90$. Dengan demikian kinerja keuangan RSUD Ciawi masuk ke dalam predikat TINGGI AA.

\section{Pengambilan Keputusan Berdasarkan Analisa Rasio Keuangan}

Berdasarkan tabel rekapitulasi dan grafik perkembangan rasio likuiditas, solvabilitas, aktivitas dan profitabilitas tersebut, maka pengambilan keputusan RSUD Ciawi Kabupaten Bogor sebagai berikut.

1. Keseluruhan tingkat likuiditas pada akhir periode analisis tahun 2014 mengalami kenaikan dari tahun 2013, kenaikan ini disebabkan adanya kenaikan nilai kas. Penilaian tingkat likuiditas dapat dikatakan baik walaupun nampak kurang ideal pada rasio posisi kas. Keputusan yang dapat diambil yaitu mempertahankan likuiditas dan melakukan investasi untuk peningkatan pelayanan rumah sakit.

2. Keseluruhan tingkat solvabilitas pada akhir periode analisis tahun 2014 mengalami penurunan, namun dapat dikatakan sangat baik dan tidak ada kekhawatiran kondisi keuangan rumah sakit dalam menutup hutang-hutangnya. Keputusan yang dapat diambil yaitu memepertahankan tingkat solvabilitas.

3. Keseluruhan tingkat aktivitas pada akhir periode analisis tahun 2014 mengalami kenaikan dari tahun 2013 dan dapat dikatakan baik, kecuali perputaran modal kerja yang tidak mengalami kenaikan atau penurunan. Khusus untuk perputaran total asset perusahaan selama periode analisis menunjukkan nilai yang berfluktuatif. Pada tahun 2011 sebesar 81,60 persen kemudian pada tahun 2012 sebesar 101,78 persen, pada tahun 2013 menurun menjadi 81,13 persen dan pada tahun 2014 mengalami kenaikan menjadi 130 persen, dengan rata-rata nilai rasio sebesar 99 persen artinya setiap Rp100,- asset rumah sakit dapat menghasilkan penjualan Rp99. Apabila melihat patokan umum rasio ini dinilai rendah, mungkin karena rumah sakit dalam kegiatannya melayani kesehatan masyarakat yang tidak berorientasi profit. Keputusan yang dapat diambil yaitu memepertahankan tingkat aktivitas, dan harus ada evaluasi terhadap pemanfaatan nilai asset untuk menghindari adanya asset yang kurang produktif.

4. Keseluruhan tingkat profitabilitas pada akhir periode analisis tahun 2014 mengalami kenaikan. Pada tahun 2014 semua nilai rasio profitabilitas mengalami kenaikan dengan kenaikan rata-rata mencapai 20 persen. Kenaikan tersebut seiring dengan naiknya pendapatan rumah sakit yang bersumber dari jasa layanan walaupun biaya operasi dan biaya umum dan administrasi masih tinggi, hal ini dapat dilihat dari perhitungan rasio operasi (Base Cost Pro- ductivity/ operating ratio ) yang mencapai 82,81 persen, mengakibatkan dana yang tersedia untuk laba bersih/surplus operasional menjadi kecil sehingga sangat berpengaruh terhadap tingkat pengembalian investasi dan tingkat pengembalian modal sendiri.

Keputusan yang dapat diambil yaitu jika memungkinkan melakukan peninjauan terhadap penyesuaian tarif layanan karena dikhawatirkan belanja barang dan jasa yang dipergunakan untuk pelayanan sudah tidak sesuai lagi dengan tarif layanan yang berlaku saat ini, meningkatkan pelayanan agar pendapatan semakin meningkat dan pengendalian biaya layanan dan biaya administrasi dan umum.

\section{KESIMPULAN}

Kesimpulan yang dapat diambil dari penelitian ini adalah sebagai berikut :

1. Analisa rasio keuangan pada RSUD Ciawi Kabupaten Bogor melalui rasio likuiditas, rasio solvabilitas dan rasio aktivitas selama periode analisis yaitu tahun 2011-2014 menunjukkan nilai yang baik. Untuk rasio profitabilitas menunjukkan nilai yang masih rendah. Rendahnya peniliaian profitabilitas tersebut disebabkan tingginya biaya operasi dan biaya umum dan administrasi. Penilaian kinerja keuangan satuan kerja Badan Layanan Umum Daerah RSUD Ciawi 
Kabupaten Bogor pada tahun 2011-2012 masuk ke dalam predikat TINGGI AA. Pada tahun 2013 masuk ke dalam predikat TINGGI A dan pada tahun 2014 masuk ke dalam predikat TINGGI AA. Hal ini menunjukkan bahwa RSUD Ciawi Kabupaten Bogor sudah berhasil dalam melaksanakan Pola Pengelolaan Keuangan BLUD meskipun masih ditopang dengan pendapatan yang bersumber dari APBD dan APBN.

2. Pengambilan keputusan keuangan yang sebaiknya dilakukan yaitu mempertahankan tingkat likuiditas, solvabilitas dan aktivitas. Untuk tingkat profitabilitas yang masih rendah keputusan keuangan yang sebaiknya dilakukan, jika memungkinkan adalah peninjauan terhadap penyesuaian tarif layanan karena dikhawatirkan belanja barang dan jasa yang dipergunakan untuk pelayanan sudah tidak sesuai lagi dengan tarif layanan yang berlaku saat ini, dan pengendalian biaya layanan dan biaya administrasi umum yang tinggi.

\section{DAFTAR PUSTAKA}

Belkaoui, Ahmed, Riahi, 2000, Accounting Theory, 4 edition, diterjemahkan oleh Marwata, Harjanti Widiastuti, Ch. Heni Kurniawan dan Alia Ariesanti, 2000, Teori Akuntansi, Buku 1, Salemba Empat, Jakarta.

C. Van Horne James dan M. Wachoiwicz John, Jr, 1997 Diterjemahkan Oleh Heru Sutojo, Prinsip-prinsip Manajemen Keuangan, Salemba Empat, Jakarta.

Djarwanto, 2004, Pokok-Pokok Analisis Laporan Keuangan, Edisi Kedua, BPFE, Yogyakarta.

Dwi Kushardini, Lely, 2006, Analisis Kinerja Keuangan Rumah Sakit berdasarkan Rasio Keuangan studi kasus pada RSU dr. Saiful Anwar Malang, Tesis, Pascasarjana Universitas Muhammadiyah, Malang.

Harahap, Sofyan Syafrie, 2002, Teori Akuntansi Laporan Keuangan, Edisi Ke satu, Cetakan ke tiga, Bumi Aksara, Jakarta.
, 2008, Analisis Kritis atas

Laporan Keuangan, Edisi Pertama, Raja Grafindo Persada, Jakarta.

Husnan, Suad dan Enny Pudjiastuty, 2002, Dasar-Dasar Manajemen Keuangan, Edisi Ketiga, Cetakan Pertama, UPP AMP YKPN, Yogyakarta.

Juan Ng Eng dan Ersa Tri Wahyuni, 2012, Panduan Praktis Standar Akuntansi Keuangan, Salemba Empat, Jakarta.

Jumingan, 2014, Analisis Laporan Keuangan, Cetakan Kelima, Bumi Aksara, Jakarta.

Kasmir, 2002, Bank dan Lembaga Keuangan Lainnya, Edisi Ke empat, PT. Grafindo Persada, Jakarta.

Keputusan Menteri Kesehatan No. 156/MENKES/SK/2003/ Tanggal 28 Januari 2003, Tentang Pedoman Akuntansi Rumah Sakit.

Masyhuda Irmawati, 2013, Kinerja Keuangan Rumah Sakit PKU Muhammadiyah Yogyakarta Berdasarkan Analisis Rasio Keuangan, Tesis, Pascasarjana Universitas Muhammadiyah, Yogyakarta.

Meidyawati, 2011, Analisis Implementasi Pola Pengelolaan Keuangan Badan Layanan Umum (Ppk-Blu) Pada Ruma Sakit Stroke Nasional Bukittinggi, Buki Tingggi.

Munawir, 2013, Analisa Laporan Keuangan, Edisi Ke empat, Cetakan Keempat Belas, Liberty. Yogyakarta.

Peraturan Direktur Jenderal Perbendaharaan Nomor PER-36/PB/2012, Pedoman Penilaian Kinerja Keuangan Satuan Kerja Badan Layanan Umum. Direktorat Jenderal Perbendaharaan Kementerian Keuangan Republik Indonesia.

Peraturan Menteri Dalam Negeri Nomor 61 Tahun 2007, Pedoman Teknis Pengelolaan Keuangan Badan Layanan Umum Daerah, Kementerian Dalam Negeri Republik Indonesia. 
Peraturan Menteri Keuangan Nomor 76/PMK.05/2008, Pedoman Akuntansi Dan Pelaporan Keuangan Badan Layanan Umum. Kementerian Keuangan Republik Indonesia.

Peraturan Pemerintah Nomor 23 Pasal 1 Angka 1 Tahun 2005 Tentang Pengelolaan Badan Layanan Umum.

Prayoga Dedy, 2011, Analisis Kinerja Keuangan Rumah Sakit Pada RSUD Dr. H. Abdul Moeloek Provinsi Lampung, Lampung : 28 Oktober, Halaman 1.

Simamora, Henry, 2002, Akuntansi Manajemen, Cetakan Pertama Edisi 2, UPP AMP YKPN, Jakarta.

Standar Akuntansi Keuangan, 2002, Standar Akuntansi Keuangan Per 1 April 2002, Cetakan Kelima, Salemba Empat, Jakarta.

Stice, James, D, dan Earl K Stice., dan K. Fred Skousen., 2009, Intermediate Accounting, 16 Edition, diterjemahkan oleh Ali Akbar, 2009, Akuntansi Keuangan, Buku 2 Edisi 16, Salemba Empat Jakarta.
Sujarweni, V, Wiratna, 2014, Metodologi Penelitian, Cetakan Pertama, Pusataka Baru Proses, Yogyakarta.

Sundarwati, 2012, Analisis Kinerja Keuangan PPK-BLUD Rumah Sakit Daerah dr. GHR, Provinsi Jawa Tengah.

Sutrisno, 2009, Manajemen Keuangan Teori Konsep dan Aplikasi, Cetakan Ketujuh, Ekoisia,Yogyakarta.

Undang-undang Republik Indonesia Nomor 1 Tahun 2004, Tentang Perbendaharaan Negara.

Undang-undang Republik Indonesia Nomor 15 Tahun 2005, Tentang Pemeriksaan Keuangan Negara.

Undang-undang Republik Indonesia Nomor 17 Tahun 2007, Tentang Keuangan Negara.

Undang-undang Republik Indonesia Nomor 44 Tahun 2009, Tentang Rumah Sakit.

Utari, Dewi, Ari Purwanti, dan Darsono Prawironegoro, 2014, Manajemen Keuangan, Cetakan Pertama, Mitra Wacana Media, Jakarta. 